\title{
First description of autochthonous canine visceral leishmaniasis in the metropolitan region of Vitória, State of Espírito Santo, Brazil
}

\author{
Marco André Loureiro Tonini ${ }^{[1]}$, Elenice Moreira Lemos ${ }^{[1]}$, Alexandre Barbosa Reis ${ }^{[2]}$, \\ Wendel Coura Vital ${ }^{[2]}$, Edelberto Santos Dias $^{[3]}$ and Reynaldo Dietze ${ }^{[1]}$
}

[1]. Núcleo de Doenças Infecciosas, Universidade Federal do Espírito Santo, Vitória, ES. [2]. Núcleo de Pesquisas em Ciências Biológicas, Universidade Federal de Ouro Preto, Ouro Preto, MG. [3]. Laboratório de Leishmanioses, Centro de Pesquisas René Rachou, Fundação Oswaldo Cruz, Belo Horizonte, MG.

\section{ABSTRACT}

Introduction: We investigated autochthonous canine visceral leishmaniasis (CVL) in the metropolitan region of Vitória (MRV), an area in which a human case was previously reported. Methods: Serological, parasitological, and molecular tests were performed in 201 dogs. Results: Twenty-six (13\%) and 12 (6\%) dogs were identified as positive using in-house enzyme-linked immunosorbent assay (ELISA) and rK39 tests, respectively. Two dogs had a positive culture for Leishmania chagasi, and 4 were polymerase chain reaction (PCR)-positive for Leishmania spp. One positive dog belonged to the aforementioned patient. Conclusions: Although the responsible vector was not found, our results provide evidence of autochthonous CVL in the MRV, a non-endemic area for VL.

Keywords: Autochthonous canine visceral leishmaniasis. Metropolitan region of Vitória. Non-endemic area for visceral leishmaniasis

In the early 1950s, visceral leishmaniasis (VL) was typically a rural disease concentrated chiefly in northeast Brazil ${ }^{1}$. However, since the early 1980 s the disease changed its epidemiological pattern, and is now characterized by geographic expansion with a tendency towards urbanization ${ }^{2}$. Currently, 21 of the 27 states of Brazil in all 5 regions of the country report autochthonous transmission of VL, encompassing 1,904 municipalities $^{3}$. To date, autochthonous canine (CVL) and human VL cases have been recorded in 11 capitals: São Luis, Teresina, Fortaleza, Natal, João Pessoa, Aracaju, Palmas, Campo Grande, Brasília, Belo Horizonte, and Rio de Janeiro, as well as in middle-sized towns with more than 100,000 inhabitants such as Montes Claros, Uberlândia, Sabará, Caxias, Araçatuba, Bauru, Piracicaba, and Varzea Grande $^{3}$. Although the annual number of reported human VL cases remain stable, an increase in the number of outbreaks is expected at some point in the future. This assumption is based on an increase over the past 15 years of people at risk for infection in new endemic areas, and also because there are an unknown number of areas in which CVL already exists without active human transmission, an epidemiological hallmark that generally precedes human cases ${ }^{4}$.

In the State of Espírito Santo, 10 municipalities located in the northwestern area are endemic for $\mathrm{VL}^{5}$. In 2006, a canine sera screening study performed in stray dogs captured in the metropolitan region of Vitória (MRV), a VL-free area, detected $4.4 \%$ (7/158) of positive animals by an immunochromatographic rK39 test (R Dietze: unpublished data). Although not parasitologically proven, these cases supported the hypothesis of the existence of autochthonous CVL transmission in the MRV. Eighteen months later, a patient from the municipality of Serra in the MRV died of VL. To investigate the existence of CVL transmission in this city, we conducted an epidemiological study, which included serological, parasitological, and molecular assays in dogs from the urban area of Serra, and an entomological investigation in areas suspected of having canine cases.

Address to: Dr. Reynaldo Dietze. NDI/UFES. Avenida Marechal Campos 1468, Maruípe, 29040-091 Vitória, ES, Brasil.

Phone: 5527 3335-7208; Fax: 5527 3335-7204

e-mail: rdietze@ndi.ufes.br

Received in 03/05/2011

Accepted in 30/09/2011
During a 7-month period (November 2008 to May 2009), 201 dogs were screened for CVL infection. These animals had been captured on the streets or brought in by their owners and were kept in the Zoonosis Control Center (ZCC) of Serra. Of these animals, $119(59.2 \%)$ belonged to the Andre Carlone neighborhood where the human VL case was reported. Sera, plasma, and buffy coat samples were obtained from all 201 dogs and used to perform serological (Kalazar Detect Canine ${ }^{\mathrm{TM}}$ [InBios International, Seattle, WA, USA], in house enzyme-linked immunosorbent assay [ELISA]), ELISA and indirect immunofluorescence tests (IIF; Biomanguinhos, Oswaldo Cruz Foundation, FIOCRUZ), and molecular assays (polymerase chain reaction [PCR]). Additionally, bone marrow aspirates were also obtained from all Kalazar Detect ${ }^{\mathrm{TM}}$ positive dogs, and aliquots were used for parasitological and molecular tests. Seropositive stray dogs were necropsied and fragments of liver and spleen were used for parasitological confirmation of VL. The Kalazar Detect ${ }^{\mathrm{TM}}$ test was performed according to manufacturer's instructions. IIF and ELISA were conducted at the State Central Lab (LACEN) following manufacturer's instructions. The in-house ELISA was performed as described elsewhere ${ }^{6}$. Briefly, anti-Leishmania immunoglobulin $\mathrm{G}$ (IgG) was detected using soluble L. chagasi (MHOM/BR/1070/BH46) promastigotes as antigens.

Slides smears from bone marrow, liver, and spleen aspirates were stained with Diff Quick (Fisher Scientific, Waltham, MA, USA) to detect Leishmania amastigotes. Pulverized spleen and liver fragments and bone marrow aspirates were inoculated into a biphasic culture medium (Novy-MacNeal-Nicolle and Liver Infusion Tryptose) to detect Leishmania promastigotes.

A commercial kit (Wizard ${ }^{\circledR}$ Genomic DNA Purification Kit, Promega, Madison, WI, USA) was used to extract DNA from Leishmania promastigotes isolated in culture or from bone marrow and/or buffy coat. DNA was subjected to PCR using primers that amplify a 120-bp sequence of the conserved region of kDNA minicircles of Leishmania spp ${ }^{7}$. Positive controls of genomic DNA of Leishmania (Leishmania) chagasi (MHOM/BR/74/PP75), Leishmania (Viannia) braziliensis (MHOM/ $\mathrm{BR} / 75 / \mathrm{M} 2903$ ), and Leishmania (Leishmania) amazonensis (MHOM/ $\mathrm{BR} / 73 / \mathrm{M} 2269$ ) were used in all assays. A restriction fragment length 
polymorphism (RFLP) test was performed on the 120-bp fragments amplified from DNA for Leishmania spp. identification ${ }^{8}$.

An entomological investigation using Centers for Disease Control (CDC) light traps was conducted in the André Carlone and Carapina neighborhoods, where human and canine cases of $V L$ were recorded. The selection of residences in which CDC traps were installed was based on the occurrence of CVL and the human VL cases as well as the presence of ecological and environmental conditions favoring the reproduction of phlebotomine sand flies, including the presence of organic material, plants, domestic animals, or poultry. The traps were installed between 5:00-6:00pm and removed at 8:00am the following day. Captures were performed at least once a week from September 2009 to February 2010. The insects that were collected were preserved in $70 \%$ ethanol and sent to the Leishmaniasis Laboratory at Rene Rachou Research Center for identification according to the protocol of Young and Duncan ${ }^{9}$.

The Animal Ethics Committee of the Federal University of Espírito Santo approved the present study.

From November 2008 to May 2009, 201 dogs from the urban area of Serra municipality were screened for $L$. chagasi infection. Out these, 38 were identified as positive by at least 1 test: $13 \%(26 / 201)$ by in-house ELISA, 6\% (12/201) by rK39 dipstick, and 3\% (6/201) by PCR. Among these 38 dogs, 2 (1\%) had a positive culture, 6 (3\%) were positive by both PCR and rK39, and 3 (1.5\%) were seropositive by both in-house ELISA and rK39. Since the ELISA and IIF tests performed in the state lab (LACEN) provided negative results in all animals, sera from all 38 positive dogs were also retested at the National VL Reference Laboratory, Fundação Ezequiel Dias (FUNED), in Belo Horizonte. Only 6 animals were found to be positive: 5 by IIF and 1 by ELISA.

The parasites isolated from bone marrow of the 2 dogs mentioned above were identified as $L$. chagasi. Positive PCR results in 4 dogs were identified as belonging to the Leishmania genus. Among the infected dogs, only 1 (rK39 and PCR positive) showed clinical signs suggestive of CVL.

Although Lutzomyia longipalpis was not detected during the study, we were able to capture another 19 phlebotomine specimens (Table 1). All phlebotomines were found within a 700-m radius of the house of the VL patient.

TABLE 1 - Phlebotomine sand flies separated by gender and species, collected in André Carlone and Carapina Grande neighborhoods, Serra, Espírito Santo, Brazil.

\begin{tabular}{lccc}
\hline Species & Males & Females & Total \\
\hline Lutzomyia edwardsi & 1 & 1 & 2 \\
Lutzomyia tupynambai & 1 & 6 & 7 \\
Lutzomyia cortelezzii & 5 & 3 & 8 \\
Lutzomyia sordellii & 1 & - & 1 \\
Lutzomyia intermedia & - & 1 & 1 \\
\hline Total & $\mathbf{8}$ & $\mathbf{1 1}$ & 19 \\
\hline
\end{tabular}

The geographic spread and urbanization of VL in Brazil has been a challenge for the Brazilian VL Control Program. Due to this and in an attempt to slow down the spread of disease, expanded surveillance and control measures have also been implemented in areas without human or canine cases ${ }^{10}$. Our study was able to identify a new VL-endemic area, which should now be included in the VL national surveillance program. Numerous other silent areas may exist in Brazil, particularly if we consider the low detection rate of the tests (ELISA and IIF) used by the VL National program as a screening tool to identify these areas. This new identified area is of great epidemiological importance, as it is part of the MRV that has 1.7 million inhabitants. As reported by others ${ }^{11}$, the urbanization of VL in areas where human immunodeficiency virus (HIV) is also prevalent poses an additional risk of disease reactivation in patients co-infected with HIV. It has been shown that the rate of VL infection/disease is about 20:12,13. In Brazil, approximately 3,500 VL cases have been reported each year for the past 10 years ${ }^{10}$. Therefore, we can assume that during this period, roughly 665,000 asymptomatic infections occurred. This number needs to be considered in the epidemiologic equation in areas in which HIV coexists in a reasonable prevalence. This scenario can be found in urban areas or when immigration occurs in both directions. The VL patient from our study had a positive HIV test detected retrospectively during the investigation and could fit well into any of these hypotheses. Thus, we cannot confirm autochthonous transmission since she was born in an endemic VL area (Barra de São Francisco) located in the northwest region of Espírito Santo where she often used to visit. However, in favor of local transmission, we can argue that there was no reported VL cases in her hometown over the past 10 years ${ }^{14}$, and that both of her dogs, 1 with a positive culture and the other with a positive rK39 test, were born and bred in Andre Carlone, Serra, and never left her house. The capture of a stray dog with a positive culture for $L$. chagasi only $550 \mathrm{~m}$ away from the VL patient residence and the finding of 4 PCR-positive dogs in the surroundings of her dwelling reinforce the hypothesis of autochthonous transmission.

The absence of Lutzomyia longipalpis in our captures does not exclude its existence in the studied area. It is possible that this species could not be found due to the small number of capture attempts and the short capture time (69 captures in 16 days during a 6-month period). Although Lutzomyia longipalpis was not encountered, others phlebotomine species were captured nearby the residence of the human VL case. Among the species captured, only Lutzomyia intermedia is of epidemiological importance, as it is considered a vector of American tegumentary leishmaniasis (ATL). Although there are no records of ATL in André Carlone, the presence of this species indicates a possibility of ATL transmission in this neighborhood.

In conclusion, despite the fact that the vector could not be found, the results of our study provide strong evidence of autochthonous transmission of CVL in Serra City. Due to the proximity of the municipalities of the MRV, there is an urgent need for a largescale canine seroepidemiological investigation and a systematic phlebotomine capture study in additional localities in order to assess the extension of the infection.

\section{ACKNOWLEDGMENTS}

We thank Virginia Emerick, Carla Cavalcanti Teixeira, and Joelson Simões from the Zoonosis Control Center (ZCC) of Serra for their indispensable support in this epidemiological investigation.

\section{CONFLICT OF INTEREST}

The authors declare that there is no conflict of interest. 


\section{ABSTRACT IN PORTUGUESE}

\section{Primeira descrição de leishmaniose visceral canina autóctone na Região Metropolitana de Vitória, Estado do Espírito Santo, Brasil}

Introdução: Descrevemos um foco de leishmaniose visceral canina (LVC) autóctone na Região Metropolitana de Vitória (RMV) onde um caso humano foi registrado anteriormente. Métodos: Testes sorológicos, parasitológicos e moleculares foram realizados em 201 cães. Resultados: Vinte e seis (13\%) e 12 (6\%) foram positivos para um teste ELISA in house e rK39, respectivamente. Dois cães apresentaram cultura positiva para Leishmania (Leishmania) chagasi e quatro PCR positivo para Leishmania spp. Um dos cães positivo pertencia ao paciente supracitado. Conclusões: Embora o vetor não tenha sido encontrado, nossos resultados fornecem evidências da LVC autóctone na RMV, área não-endêmica para leishmaniose visceral.

Palavras-chaves: Leishmaniose visceral canina autóctone. Região Metropolitana de Vitória. Área não-endêmica para leishmaniose visceral.

\section{REFERENCES}

1. Deane LM. Leishmaniose visceral no Brasil: Estudos sobre reservatórios e transmissores realizados no estado do Ceará. Rio de Janeiro: Serviço Nacional de Educação Sanitária; 1956.

2. Werneck GL. Geographic spread and urbanization of visceral leishmaniasis in Brazil. Introduction. Cad Saude Publica 2008; 24:2937-2940.

3. Maia-Elkyhoury ANS, Alves WA, Sousa-Gomes ML, Sena JM, Luna EA. Visceral leishmaniasis in Brazil: trends and challenges. Cad Saude Publica 2008; 24:2941-2947.

4. Galimbertti MZ, Katz G, Camargo-Neves VL, Rodas LAC, Casanova C, Costa IP. Leishmaniose visceral americana no Estado de São Paulo. Rev Soc Bras Med Trop 1999; 32:217-218.
5. Secretaria de Saúde do Estado do Espírito Santo. Série histórica dos casos notificados do período 1986-2004. Vitória: Programa de Controle das Leishmanioses. Secretaria do Estado do Espírito Santo; 2004.

6. Rosário EY, Genaro O, França-Silva JC, Costa RT, Mayrink W, Reis AB, et al. Evaluation of enzyme-linked immunosorbent assay using crude Leishmania and recombinant antigens as a diagnostic marker for canine visceral leishmaniasis. Mem Inst Oswaldo Cruz 2005; 100:197-203.

7. Degrave W, Fernandes O, Campbell D, Bozza M, Loppes U. Use of molecular probes and PCR for detection and typing of Leishmania - a mini review. Mem Inst Oswaldo Cruz 1994; 89:463-469.

8. Volpini AC, Passos VM, Oliveira GC, Romanha AJ. PCR-RFLP to identify L. (V.) braziliensis and L. (L.) amazonensis causing American cutaneous Leishmaniasis. Act Tropica 2004; 90:31-37.

9. Young DG, Duncan MA. Guide to the identification and geographic distribution of Lutzomyia sand flies in Mexico, the West Indies, Central and South America (Diptera, Psychodidae). Mem Am Entomol Inst 1994; 54:1-881.

10. Ministério da Saúde. Manual de Vigilância e Controle da Leishmaniose Visceral. Brasília: Secretária de Vigilância em Saúde; 2006.

11. Desjeux P, Alvar J. Leishmania/HIV co-infections: epidemiology in Europe. Ann Trop Med Parasitol 2003; 97:3-15.

12. Badaro R, Jones TC, Carvalho EM, Sampaio D, Reed SG, Barral A, et al. New perspectives on a subclinical form of visceral leishmaniasis. J Infect Dis 1986; 154: 1003-1011.

13. Dietze R, Barros GB, Teixeira L, Harris J, Michelson K, Falqueto A, et al. Effect of Eliminating Seropositive Canines on the Transmission of Visceral Leishmaniasis in Brazil. Clin Infect Dis 1997; 25:1240-1242.

14. Ministério da Saúde. Sistema de Informação de Agravos de Notificação [Internet]. [updated 2009 Apr 27; cited 2011 Jan 20]. Available from: http://dtr2004.saude. gov.br/sinanweb/index.php. 